\title{
EFFECTS OF CLIMATE AND AGRICULTURAL PRACTICES ON THE ECOPHYSIOLOGY OF PIGEONPEA IN THE SOUTHEASTERN UNITED STATES
}

\author{
Corie Wilson, ${ }^{a}$ Dafeng Hui, ${ }^{a}{ }^{*}$ Fisseha Tegegne, ${ }^{b}$ Eemka Nwaneri, ${ }^{a}$ Chloe Davidson, ${ }^{a}$ Desh Duseja ${ }^{b}$ \\ ${ }^{a}$ Department of Biological Sciences, Tennessee State University, Nashville, TN 37209, USA. \\ ${ }^{\mathrm{b}}$ Department of Agricultural and Environmental Sciences, Tennessee State University, Nashville, TN 37209, USA. \\ *Corresponding author: dhui@ tnstate.edu, Tel: +86-1-615-963-5777, Fax: +86-1-615-963-5783
}

\begin{abstract}
Many factors such as climate and agricultural practices influence the ecophysiology of legume crops. As an important legume crop, pigeonpea (Cajanus cajan) has been grown mainly in arid, semi-arid tropical and subtropical regions of the World. However, performance of pigeonpea in southeastern United States has not been extensively investigated. To test the effects of climate and agricultural practices on the ecophysiology of pigeonpea, we conducted a two-year field experiment in Nashville, Tennessee. Precipitation during the growing season showed contrasting patterns with fall drought in 2010 and frequent precipitation in 2011. Four pigeonpea varieties at three planting densities were evaluated in both years. Measurements included maximum net leaf photosynthesis, stomatal conductance, transpiration, water use efficiency (WUE), leaf area index (LAI), and soil respiration. We found strong interannual variations in all variables investigated. Leaf photosynthetic rates, stomatal conductance, transpiration and LAI were significantly higher in 2011 than in 2010. The high values observed in 2011 were mainly due to high precipitation rates during and after the flowering time. Pigeonpea varieties G1 and W3 had higher photosynthetic rates and LAI while variety W3 had the highest WUE. Planting density did not influence these ecophysiological variables except for plant transpiration. Our results indicated that variety selection could improve pigeonpea performance under varying climatic conditions. Although pigeonpea varieties are adaptable to drought, irrigation and growing in moist climatic regions could significantly enhance its ecophysiological performance and yield.
\end{abstract}

Keywords: Density; Photosynthesis; Leaf area index; Soil Respiration; Transpiration; Variety; Water use efficiency.

\section{Introduction}

Crop physiology, development and yield are regulated by factors such as climate, varieties, crop species, and management practices. For example, crop species have been reported to differ in their responses to climatic factors such as temperature, precipitation and soil water deficits [1-3]. Crops that were grown under drought conditions often perform poorly in physiology and yields than those that were grown in water stress-free environments [4]. Several studies have been reported that periods of water stress can adversely affect crop yields due to its effects on physiological responses such as stomatal conductance [4,5] and transpiration [6]. Drought and heat waves in northern Italy in 2003 significantly reduced maize productivity by $36 \%$ [7, 8]. Differing agricultural practices can have significant influences on crop physiology and growth. For example, the selection of tolerant variety of crops has been shown to be an effective way to improve plant ecophysiology and yield $[9,10]$. Planting density may also influence crop yield $[11,12]$. Thus, understanding how a crop responds to climatic stresses and agricultural practices is important for improving yield and sustainability.

Pigeonpea [Cajanus cajan (L.) Millsp.] is traditionally grown as a dryland grain crop in the arid and semi-arid tropical and subtropical regions of the world. It is mainly grown in India, Africa, and the
Caribbean [13-15]. More recently it has been grown in the drought-striken Karst regions of southwest China [16], in Australia [17, 18], and in the US $[9,10,19]$. Different pigeonpea varieties are tested for grain and forage production in some southern states including Georgia, Florida, Oklahoma, and Virginia $[9,13,20,21]$. Incorporating pigeonpea into cropping systems used in the southern Great Plains and southeastern the United States could provide farmers in those regions with a variety of new services such as summer forage, biological nitrogen fixation, and new grain crops [22]. Unfortunately, these regions are often stricken with severe summer and fall droughts.

As global warming continues, changes in climate, particularly extreme temperatures and low and variable precipitation rates are anticipated. These changes will have pronounced influences on crop ecophysiology and production. Few studies have been conducted under field environments to compare physiological responses of pigeonpea to climate change. Foster et al. (2009) reported that inadequate precipitation can delay the establishment of pigeonpea [19]. Water stress has been reported to decrease leaf-water status and stomatal conductance in pigeonpea [1]. Critical knowledge gaps related to the effect of climate and agricultural practices on pigeonpea exist $[22,23]$. 
The objective of this study was to evaluate plant ecophysiology of pigeonpea in response to naturally occurring climate change and agricultural practices in Middle Tennessee. Since leaf photosynthesis, transpiration, and water use efficiency are important biological processes that directly influencing plant growth and production, these variables were investigated in this study. Four varieties of pigeonpea were planted at three different densities in a two years study. Contrasting precipitation patterns and quantified effects of varieties, planting densities, and year (climate) effects on eco-physiological responses of pigeonpea were evaluated. The knowledge gained from this study has improved our understanding of the performance of pigeonpea variety under stressful climatic changes for food production.

\section{Materials and Methods}

\section{Experimental site, experimental design and treatments}

This field experimental study was conducted in 2010 and 2011 at Tennessee State University Agricultural Research and Demonstration Center (Latitude 36.12' N, Longitude $36.98^{\prime} \mathrm{W}$, elevation $127.6 \mathrm{~m}$ ) in Nashville, Tennessee. This center is located at the north end of the campus. Soil of experimental plots was an Armour silt loam soil, slightly acidic $(\mathrm{pH}=6.2)$, low in both phosphorus and potassium (see [10]).

Treatment factors used in this study were varieties and planting densities. Four varieties of pigeonpea were selected: two early maturing varieties (G1: George One and G2: Georgia Two), and two late maturing varieties (W1 and W3). Three planting spacings were 5,10 , and $15 \mathrm{~cm}$, equivalent to 295,500, 145,250, and 96,833 pants/ha, respectively. Planting dates in 2010 were 9 June and 1 July, and in 2011 , only one planting date (24 June) was applied.

In both 2010 and 2011, the density and variety treatments were replicated four times (i.e. 4 blocks). In each block, varieties and densities were randomly assigned. The total number of plots was 96 in 2010 and 48 in 2011. Plot size for both seasons was $3 \mathrm{~m} \times 2 \mathrm{~m}$. Seeds were obtained from a private company in Georgia. Fresh seeds were sown and thinned to a pre-determined density. No nitrogen or irrigation was applied. We applied $130 \mathrm{~kg} \mathrm{P} 2 \mathrm{O} 5 / \mathrm{ha}$ and $80 \mathrm{~kg} \mathrm{~K} 2 \mathrm{O} / \mathrm{ha}$ before seeds were planted. No insect/disease problems was encountered, and weed control was maintained by herbicides [10].

There were contrasting climatic conditions during both growing seasons (Fig. 1). While the total precipitation amounts were almost the same (1513.8 $\mathrm{mm}$ in 2010 and $1536.7 \mathrm{~mm}$ in 2011), a May flood and a fall drought occurred in 2010 while frequent precipitation occurred in 2011. The total amount of precipitation between September and November was only $230.48 \mathrm{~mm}$ in 2010 , compared to $337.3 \mathrm{~mm}$ in 2011. Air temperature average during 2010 was $1^{\circ} \mathrm{C}$ higher than in 2011.

Field measurements of leaf photosynthesis, stomatal conductance, transpiration, leaf area index and soil respiration

Leaf photosynthesis, stomatal conductance, and transpiration rates were measured using a Li6400 Portable Photosynthesis System (Li-Cor Inc., Lincoln, NE, USA) [10]. Two fully expanded young leaves of 2 to 3 selected plants in the center row of a plot were measured between 10:00am and 3:00pm during the peak flowering time in September and October. The photosynthetically active radiation was set at $2000 \mu \mathrm{mol}$ photon $/ \mathrm{m}^{2} / \mathrm{s}$, and the $\mathrm{CO}_{2}$ concentration was set at ambient concentration 380 400 ppm for leaf photosynthesis measurements. Water use efficiency was calculated as leaf photosynthesis / transpiration. Leaf area index (LAI) was measured using LAI 2200 Plant Canopy Analyzer (Li-COR, Inc., Lincoln, Nebraska, USA) following the procedure used for row crops [10]. Soil respiration was measured on two PVC soil collars in each plot using a Li-Cor 6400 infrared gas analyzer (Li-COR, Inc., Lincoln, Nebraska, USA) at the same time that photosynthesis measurements were taken.

\section{Statistical analysis}

The effects of year, variety, and planting density along with their interactions were analyzed using Analysis of Variance (ANOVA) [24,25]. Only when a significant effect was detected, least significant difference (LSD) was used for multiple comparisons. Data analysis was performed using SAS software ([25], SAS Inc. Cary, NC).

\section{Results and Discussion}

Of all the ecophysiological variables (leaf photosynthetic rate, stomatal conductance, transpiration, water use efficiency, LAI and soil respiration) investigated in this study, there were significant differences between the two years, caused mainly by climatic differences (Table 1). Different varieties showed significant effects on most variables. Planting density did not have significant effect on all variables. Block effect was significant for all variables except for soil respiration. There was no significant interactive effect between variety and density or between density and year (Table 1). The only significant interactive effect of variety and year was on water use efficiency. 
Pure Appl. Bio., 1(2): 33-39, Sept- 2012.

Table 1. Results of Analysis of Variance (ANOVA) to detect the effects of planting dates, varieties and densities on maximum net leaf photosynthetic rate, stomatal conductance, leaf area index and soil respiration of pigeonpea.

\begin{tabular}{|c|c|c|c|c|c|c|}
\hline Source of Variance & $\begin{array}{l}\text { Leaf Photosynthetic } \\
\text { Rate } \\
\left(\mu \mathrm{mol} \mathrm{CO} \mathrm{CO}_{2} / \mathrm{m}^{2} / \mathrm{s}\right)^{\dagger}\end{array}$ & $\begin{array}{l}\text { Stomatal Conductance } \\
\left(\mathrm{mol} \mathrm{H}_{2} \mathrm{O} / \mathrm{m}^{2} / \mathrm{s}\right)^{\dagger}\end{array}$ & $\begin{array}{l}\text { Transpiration (mmol } \\
\mathrm{H}_{2} \mathrm{O} \\
\left./ \mathrm{m}^{-2} / \mathrm{s}\right)^{\dagger}\end{array}$ & $\begin{array}{l}\text { Water Use Efficiency } \\
\left(\mu \mathrm{mol} \mathrm{CO} \mathrm{CO}_{2} / \mathrm{mmol}\right. \\
\left.\mathrm{H}_{2} \mathrm{O}\right)^{\dagger}\end{array}$ & $\begin{array}{l}\text { Leaf Area } \\
\text { Index } \\
\left(\mathrm{m}^{2} / \mathrm{m}^{2}\right)^{\dagger}\end{array}$ & $\begin{array}{l}\text { Soil Respiration } \\
\left(\mu \mathrm{mol} \mathrm{CO} 2 / \mathrm{m}^{2} / \mathrm{s}\right)^{\dagger}\end{array}$ \\
\hline Model & $151.02^{* * *}$ & $194.38^{* * *}$ & $171.10^{* * *}$ & $7.34^{* * *}$ & $21.10^{* *}$ & $4.59^{* *}$ \\
\hline Block & $39.78^{* *}$ & $71.73^{* *}$ & $89.86^{* *}$ & $11.15^{* *}$ & $3.21^{*}$ & 1.40 \\
\hline Year & $2871.95^{* *}$ & $3650.49^{* *}$ & $3109.49^{* * *}$ & $40.01^{* *}$ & $371.49^{* *}$ & $72.75^{* *}$ \\
\hline Variety & $4.50^{* *}$ & $2.42 \Delta$ & $8.3^{* *}$ & $14.59^{* *}$ & $11.82^{* *}$ & 2.04 \\
\hline Density & 1.38 & 0.66 & 0.58 & 0.15 & 0.87 & 0.80 \\
\hline Variety*Density & 0.98 & 1.48 & 0.86 & 0.62 & 0.09 & 0.88 \\
\hline Variety*Year & 0.29 & 0.54 & 2.03 & $8.36^{* *}$ & 0.67 & 0.15 \\
\hline Density *Year & 1.25 & 1.42 & $2.84^{\Delta}$ & 0.29 & 0.52 & 0.72 \\
\hline
\end{tabular}

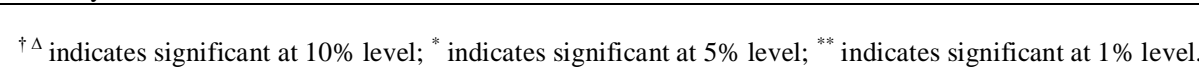

Table 2. Mean and significance of maximum leaf photosynthetic rate, stomatal conductance, leaf area index and soil respiration of pigeonpea between two years.

\begin{tabular}{|c|c|c|c|c|c|c|}
\hline Year & $\begin{array}{l}\text { Leaf Photosynthetic } \\
\text { Rate } \\
\left(\mu \mathrm{mol} \mathrm{CO} \mathrm{CO}_{2} / \mathrm{m}^{2} / \mathrm{s}\right)^{\dagger}\end{array}$ & $\begin{array}{l}\text { Stomatal } \\
\text { Conductance } \\
\left(\mathrm{mol} \mathrm{H}_{2} \mathrm{O} / \mathrm{m}^{2} / \mathrm{s}\right)^{\dagger}\end{array}$ & $\begin{array}{l}\text { Transpiration } \\
\left(\mathrm{mmol} \mathrm{H}_{2} \mathrm{O} / \mathrm{m}^{2} / \mathrm{s}\right)^{\dagger}\end{array}$ & $\begin{array}{l}\text { Water Use } \\
\text { Efficiency } \\
\left(\mu \mathrm{mol} \mathrm{CO}{ }_{2}\right. \\
\left./ \mathrm{mmol} \mathrm{H}_{2} \mathrm{O}\right)^{\dagger}\end{array}$ & $\begin{array}{l}\text { Leaf Area } \\
\text { Index } \\
\left(\mathrm{m}^{2} /\right. \\
\left.\mathrm{m}^{2}\right)^{\dagger}\end{array}$ & $\begin{array}{l}\text { Soil Respiration } \\
\left(\mu \mathrm{mol} \mathrm{CO} 2 / \mathrm{m}^{2} / \mathrm{s}\right)^{\dagger}\end{array}$ \\
\hline 2010 & $10.08 \mathrm{a}$ & $0.082 \mathrm{a}$ & $1.98 \mathrm{a}$ & $5.18 \mathrm{a}$ & $2.19 \mathrm{a}$ & $3.23 \mathrm{a}$ \\
\hline 2011 & $26.91 \mathrm{~b}$ & $0.471 \mathrm{~b}$ & $6.00 \mathrm{~b}$ & $4.64 \mathrm{~b}$ & $4.15 \mathrm{~b}$ & $2.25 \mathrm{~b}$ \\
\hline
\end{tabular}

${ }^{\dagger}$ Different letters denote significant differences among treatments.

Table 3. Mean and significance of maximum leaf photosynthetic rate, stomatal conductance, leaf area index, and soil respiration of pigeonpea among varieties.

\begin{tabular}{lllllll}
\hline Variety & $\begin{array}{l}\text { Leaf Photosynthetic } \\
\text { Rate } \\
\left(\mu \mathrm{mol} \mathrm{CO} \mathrm{CO}_{2} / \mathrm{m}^{2} / \mathrm{s}\right)^{\dagger}\end{array}$ & $\begin{array}{l}\text { Stomatal } \\
\text { Conductance } \\
\left(\mathrm{mol} \mathrm{H}_{2} \mathrm{O}\right.\end{array}$ & $\begin{array}{l}\text { Transpiration } \\
\left(\mathrm{mmol} \mathrm{H} \mathrm{O} / \mathrm{m}^{2} / \mathrm{s}\right)^{\dagger}\end{array}$ & $\begin{array}{l}\text { Water Use } \\
\text { Efficiency }(\mu \mathrm{mol} \\
\left.\mathrm{CO}_{2} / \mathrm{mmol} \mathrm{H}_{2} \mathrm{O}\right)\end{array}$ & $\begin{array}{l}\text { Leaf Area } \\
\text { Index } \\
\left(\mathrm{m}^{2} / \mathrm{m}^{2}\right)^{\dagger}\end{array}$ & $\begin{array}{l}\text { Soil Respiration } \\
\left(\mu \mathrm{mol}^{\dagger} \mathrm{CO}_{2}\right. \\
\left./ \mathrm{m}^{2} / \mathrm{s}\right)^{\dagger}\end{array}$ \\
\hline $\mathrm{G} 1$ & $0.249 \mathrm{a}$ & $3.78 \mathrm{a}$ & $5.00 \mathrm{~b}$ & $3.21 \mathrm{a}$ & $2.96 \mathrm{a}$ \\
$\mathrm{G} 2$ & $17.62 \mathrm{a}$ & $0.248 \mathrm{a}$ & $3.80 \mathrm{a}$ & $4.54 \mathrm{c}$ & $2.51 \mathrm{~b}$ & $2.97 \mathrm{a}$ \\
$\mathrm{W} 1$ & $16.89 \mathrm{~b}$ & $0.234 \mathrm{a}$ & $3.38 \mathrm{~b}$ & $4.98 \mathrm{~b}$ & $2.63 \mathrm{~b}$ & $2.72 \mathrm{a}$ \\
$\mathrm{W} 3$ & $16.11 \mathrm{~b}$ & $0.238 \mathrm{a}$ & $3.55 \mathrm{~b}$ & $5.31 \mathrm{a}$ & $3.06 \mathrm{a}$ & $2.95 \mathrm{a}$ \\
\hline
\end{tabular}

${ }^{\dagger}$ Different letters denote significant differences among treatments and same letter denotes no significant difference. 


\section{Interannual variations in ecophysiology of pigeonpea}

The mean maximum leaf photosynthetic rate in 2011 was $26.91 \mu \mathrm{mol} \mathrm{CO}_{2} / \mathrm{m}^{2} / \mathrm{s}$, significantly higher than that in 2010 (Table 2). Stomatal conductance and transpiration were also greatly enhanced in 2011 compared to 2010. LAI increased to $4.15 \mathrm{~m}^{2} / \mathrm{m}^{2}$ in 2011 from $2.19 \mathrm{~m}^{2} / \mathrm{m}^{2}$ in 2010 . Compared to leaf photosynthesis and transpiration, WUE was relative stable during the two year study. Because more water transpiration occurred in 2011 than that in 2010, WUE was slightly lower in 2011. Soil respiration was lower in 2011 compared to 2010.

The strong interannual variations in these ecophysiological variables could be mainly regulated by differences in climatic factors between the two years. We applied the same routing field maintenance in both 2010 and 2011 and used the same varieties and planting densities. However, the planting dates were different. Later planting tended to increase leaf photosynthesis and transpiration [10]. Since the planting date used in 2010 was between the two planting dates in 2011, we believe that this planting date change would not dramatically influence these ecophysiological variables. The most likely cause would be the differences in climatic factors, particularly precipitation. A severe fall drought that occurred in 2010 might have decreased leaf photosynthesis and transpiration resulted in reduced LAI. Precipitation rates during and after flowering were much higher and more frequent in 2011 than in 2010. This provided adequate soil moisture for pigeonpea plants to grow, resulting in large changes in pigeonpea ecophysiology.

Pigeonpea is a plant species adapted to semi-arid and arid environments. Thus, it can maintain a relatively high leaf photosynthesis rate under drought conditions, as demonstrated in 2010 [10]. However, under adequate water conditions these plants could significantly enhance leaf photosynthesis. We found that mean leaf photosynthetic rate was $26.91 \mu \mathrm{mol} \mathrm{CO}_{2} / \mathrm{m}^{2} / \mathrm{s}$ in 2011. This value is consistent with that reported by Lopez et al. (1988) for potted pigeonpea plant [26]. Very high leaf photosynthetic rates have also been reported for legume crops. For example, leaf photosynthesis rates for field-grown soybean were over $40 \mu \mathrm{mol} / \mathrm{m}^{2} / \mathrm{s}$ [27]. Leaf rates at or above 30 $\mu \mathrm{mol} / \mathrm{m}^{2} / \mathrm{s}$ have also been reported for field-grown peanut $[5,28]$. High leaf photosynthesis for pigeonpea in 2011 also came with high water use. In 2011, plants used 3.0 times more water than in 2010. Our result is comparable with soybean [22]. Soybean used 2.0 to 2.5 times more water during wet years than in dry years in the SGP. Thus, our results indicated that pigeonpea may be able to grow in areas that receive low to high annual precipitation, indicating that irrigation applied during critical growth stages may enhance leaf physiology and production.

Soil respiration in pigeonpea plots was relative higher in 2010 compared to that in 2011; but, the absolute values were low in both years (3.23 and $2.25 \mu \mathrm{mol} \mathrm{CO}_{2} / \mathrm{m}^{2} / \mathrm{s}$ in 2010 and 2011, respectively). The relatively low values obtained in 2011 might be related to temperature. Mean air temperature in 2011 was lower than during 2010.

\section{Effect of variety on pigeonpea ecophysiology}

Among the four varieties evaluated, the photosynthetic rate of G1 was significantly higher than G2 and W1, but not significantly different from W3 (Table 3). Net leaf photosynthetic rates varied from 16.11 to $17.62 \mu \mathrm{mol} \mathrm{CO}_{2} / \mathrm{m}^{2} / \mathrm{s}$ among four varieties. No interactive effect between variety and year was detected. This indicates that all four varieties performed equally better in 2001 than in 2010 (Fig. 2). No difference in stomatal conductance was observed. In both years, G1 and G2 had higher transpiration rates than $\mathrm{W} 3$ and $\mathrm{W} 1$. Leaf transpiration varied from $3.38 \mathrm{mmol} \mathrm{H}_{2} \mathrm{O} / \mathrm{m}^{2} / \mathrm{s}$ for W1 to $3.80 \mathrm{mmol} \mathrm{H}_{2} \mathrm{O} / \mathrm{m}^{2} / \mathrm{s}$ for $\mathrm{G} 2$.

Variety W3 had a significantly higher WUE than the other varieties $\left(5.31 \mu \mathrm{mol} \mathrm{CO} / \mathrm{mmol} \mathrm{H}_{2} \mathrm{O}\right)$. The lowest WUE obtained was for G2 (4.54 $\mu \mathrm{mol}$ $\mathrm{CO}_{2} / \mathrm{mmol} \mathrm{H}_{2} \mathrm{O}$ ). WUE of pigeonpea was relative lower compared to sorghum, but comparable to cotton and soybean [29,30]. For LAI, G1 and W2 had higher LAI than W1 and G2. G1 and W3 also grew taller than $\mathrm{G} 2$ and $\mathrm{W} 1$ in both years. The lowest LAI was $2.51 \mathrm{~m}^{2} / \mathrm{m}^{2}$ for $\mathrm{G} 2$ and the highest one was 3.21 $\mathrm{m}^{2} / \mathrm{m}^{2}$ for G1. These values were comparable to findings reported by others $[31,32]$. We did not find any significant differences in soil respiration among the varieties. The soil respiration rates were relative low in both years.

\section{Effect of planting density on ecophysiology of pigeonpea}

Plant densities did not influence the leaf photosynthetic rates, stomatal conductance, WUE, LAI, or soil respiration. Only transpiration was significantly influenced by planting density. Plants being grown in the highest density used less water than those in the middle density. Tayo (1982) also observed a similar trend on pigeonpea physiology by planting density in their study [33]. It appears that pigeonpea could be grown at different densities without influencing its ecophysiology and production. 

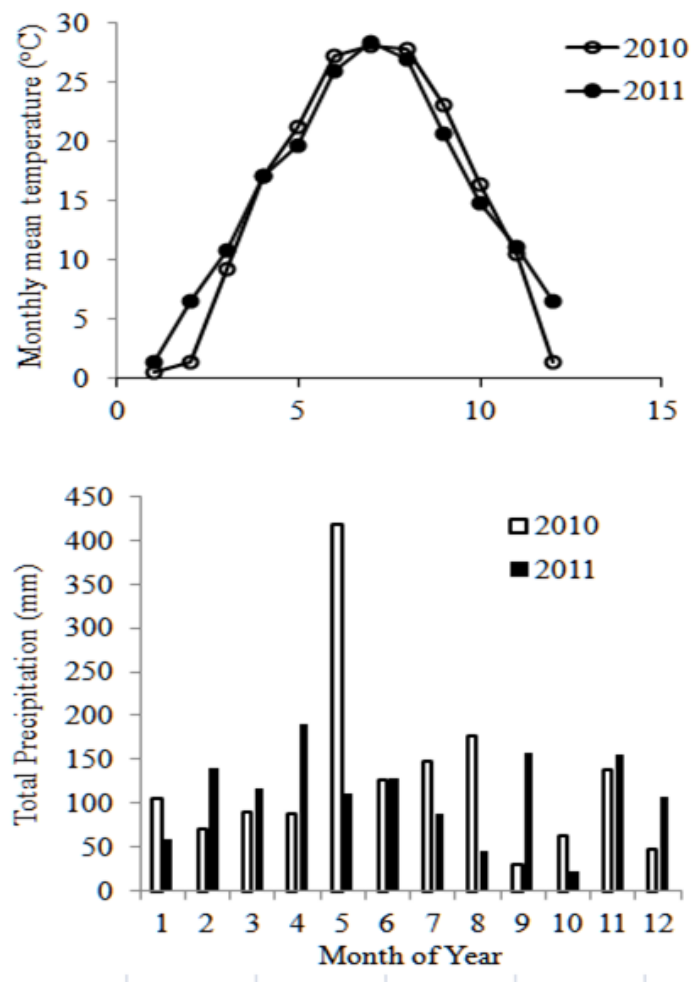

Fig. 1. Monthly mean temperature and total precipitation in Nashville. Data source: NOAA National Weather Service Weather Forecast Office, http://www.srh.noaa.gov.
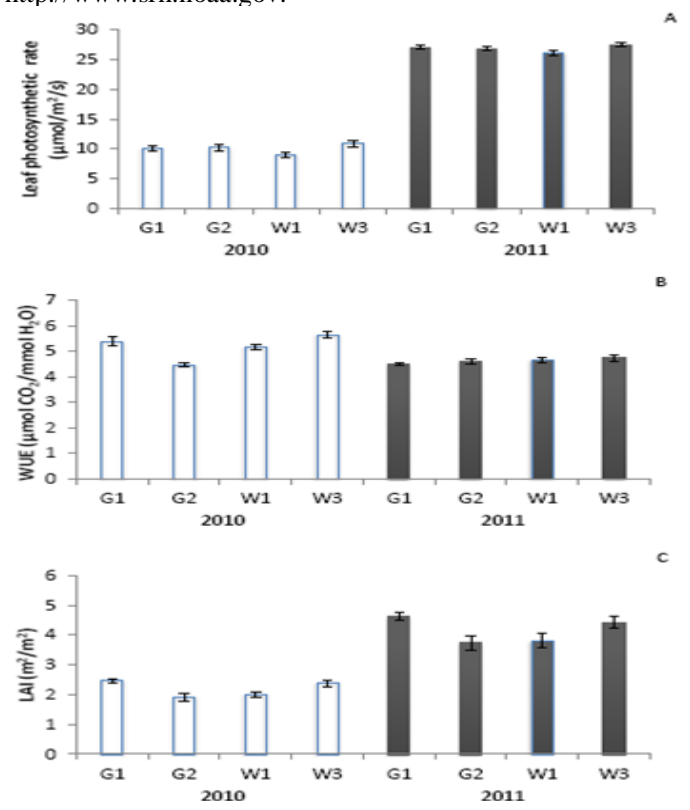

Fig. 2. Leaf photosynthetic rate, water use efficiency (WUE), and leaf area index (LAI) of four varieties in two years. Bars are standard error of measurements.

\section{Conclusions}

Climate change may significantly influence the ecophysiology of pigeonpea plant. Large precipitation during and after flowering in 2011 enhanced pigeonpea leaf photosynthesis, transpiration, and improved plant growth and LAI. Different varieties had significant differences in maximum net leaf photosynthesis, stomatal conductance, transpiration, WUE, and LAI. G1 and W3 performed better than other two varieties in both years while planting density only influenced plant transpiration. These results indicated that although pigeonpea is adapted to arid and semi-arid environments, more precipitation can enhance its ecophysiology and production. Irrigation at critical growth stages might increase pigeonpea performance. Selection of drought resistant varieties could also improve the stability of ecophysiology and production in the southeastern US where summer and fall drought are frequent.

\section{Acknowledgements}

This research was funded in part by the USDA CBG program (grant number: 2008-3881404736), the National Science Foundation (grant numbers: DBI-0923371 and DBI-0933958) and LiCor Environmental Education Fund (LEEF). Dr. Sharak Phatak, Professor Emeritus, University of Georgia, provided advice on planting protocol and selection of seed varieties. Seeds were provided by the AgResearch Consultants Inc/ACI Seeds located in Georgia. We thank Drs. Jun Wang and Qi Deng for their contributions in 2010 and students for their help in planting and field data collection.

\section{Reference}

1. DeVries JD, Bennett JM, Albrecht SL, Boote KJ (1989) Water relations, nitrogenase activity and root development of three grain legumes in response to soil water deficits. Field Crops Res. 21: 215-226.

2. Porter JR, Semenov MA (2005) Crop responses to climatic variation. Philos Trans R Soc Lond B Biol Sci. 360: 2021-2035.

3. Tubiello FN, Soussana JF, Howden SM (2007) Climate Change and Food Security Special Feature: Crop and pasture response to climate change. Proceedings of the National Academy of Sciences of the United States of America. 104:19686-19690.

4. Muchow RC (1985) Canopy development in grain legumes grown under different soil water regimes in a semi-arid tropical 
environment. Field Crops Research 11:99109.

5. Bennett JM, Sinclair TR, Ma L, Boote KJ (1993) Single leaf carbon exchange and canopy radiation use efficiency of four peanut cultivars. Peanut Sci. 20:1-5.

6. Lopez FB, Chauhan YS, Johansen C (1997) Effects of timing of drought stress on leaf area development and canopy light interception of short-duration pigeonpea. J. Agronomy \& Crop Science 178: 1-7.

7. Ciais $\mathrm{P}$, Reichstein $\mathrm{M}$, Viovy $\mathrm{N}$, et al. (2005) Europe-wide reduction in primary productivity caused by the heat and drought in 2003. Nature 437: 529-533.

8. van der Velde M, Wriedt G, Bouraoui F (2010) Estimating irrigation use and effects on maize yield during the 2003 heat wave in France. Agric Ecosyst Environ 135:90-97.

9. Rao SC, Coleman SW, Mayeux HS (2002) Forage production and nutritive value of selected pigeonpea ecotypes in southern Great Plains. Crop Science 42: 1259-1263.

10. Wilson C, Hui D, Nwaneri E, Wang J, Deng Q, Duseja D, Tegegne F (2012) Effects of planting dates, densities, and varieties on ecophysiology of pigeonpea in the southeastern United States. Agricultural Sciences 3:147-152.

11. Ofori F, Stern WR (1987) The combined effects of nitrogen fertilizer and density of the legume component on production efficiency in a maize/cowpea intercrop system. Field Crops Res. 16: 43-52.

12. Pattanaik MR, Tarai RK, Pal P (2010) Effect of Planting Time and Plant Density on Growth and Quality of Cut Flower Production of Chrysanthemum (Dendranthema grandiflora) cv Kenroku Kangiku under Polyshade in West Bengal. Environment and Ecology 28: 1451-1454.

13. Rao SC, Phillips WA, Mayeux HS, Phatak SC (2003) Potential grain and forage production of early maturing pigeonpea in the southern Great Plains. Crop Science 43: 2212-2217.

14. Odeny DA (2007) The potential of pigeonpea (Cajanus cajan (L.) Millsp.) in Africa. Natural Resources Forum 31: 297305.
15. Priyanka B, Sekhar K, Reddy VD, Rao KV (2010) Expression of pigeonpea hybridproline-rich protein encoding gene (CcHyPRP) in yeast and Arabidopsis affords multiple abiotic stress tolerance. Plant Biotechnology Journal 8:76-87.

16. Qiao G, Wen XP, Yu LF, Ji XB (2011) The enhancement of drought tolerance for pigeon pea inoculated by arbuscular mycorrhizae fungi. Plant Cell Environ. 57: 541-546.

17. Flower DJ, Ludlow NM (1987) Variation among accessions of pigeonpea (Cajanus cajan) in osmotic adjustment and dehydration tolerance of leaves. Field Crops Res. 17: 229-243.

18. Gowda GL, Saxena KB, Srivastava RK, Upadhyaya HD, Silim SN (2012) Pigeonpea: from an orphan to a leader in food legumes. In: Biodiversity in Agriculture: Domestication, Evolution, and Sustainability. P. Gepts, T.R. Famula, R.L. Bettinger, et al. (eds.). Cambridge University Press.

19. Foster JL, Adesogan AT, Carter JN, Sollenberger LE, Blount AR, Myer RO, Phatak SC, Maddox MK (2009) Annual legumes for forage systems in the United States Gulf Coast Regioin. Agronomy Journal 101: 415-421.

20. Phatak SC, Nadimpalli RG, Tiwari SC, Bhardwaj HL (1993) Pigeonpeas: Potential new crop for the southeastern United States. In: New Crops. J. Janick and J.E. Simon (eds.). Wiley, New York.

21. Bhardwaj HL, Rangappa M, Hamama AA (1999) Chickpea, faba bean, lupin, mungbean, and pigeonpea: potential new crops for the Mid-Atlantic Region of the United States. In: Perspectives on new crops and new uses. J. Janick (ed.). ASHS Press, Alexandria, VA, pp. 202-205.

22. Rao SC, Northup BK (2009) Capabilities of four novel warm-season legumes in the Southern Great Plains: Biomass and forage quality. Crop Sci. 49: 1096-1102.

23. Rao SC, Northup BK (2012) Pigeon Pea Potential for Summer Grazing in the Southern Great Plains. Agron. J. 104: 199203. 
24. Carmer SG, Walker WM (1985) Pairwise multiple comparisons of treatment means in agronomic research. J. Agron. Educ. 14: 1926.

25. Hui D, Jiang C (1996) Practical SAS Usage. Beijing University of Aeronautics \& Astronautics Press, Beijing, China.

26. Lopez FB, Setter TL, McDavid CR (1988) Photosynthesis and water vapor exchange of pigeonpea leaves in response to water deficit and recovery. Crop Sci. 28:141-145.

27. Sinclair TR (1980) Leaf CER from postflowering to senescence of field-grown soybean cultivars. Crop Sci. 20:196-200.

28. Bell MJ, Wright GC, Suryantini D, Peoples MB (1994) The N2-fixing capacity of peanut cultivars with differing assimilate partitioning characteristics. Aust. J. Agric. Res. 45:1455-1468.

29. Allen LH Jr, Pan D, Boote KJ, Pickering NB, Jones JW (1995) Carbon dioxide and temperature effects on evapotranspiration and water use efficiency of soybean. Agronomy Journal 95: 1071-1081.

30. Xin Z, Aiken R, Burke J (2009) Genetic diversity of transpiration efficiency in sorghum. Field Crops Research 111: 74-80.

31. Balakrishnan K, Natarajaratnam $\mathrm{N}$, Rajendran C (1987) Influence of sowing date on photosynthesis and production of Cajanus cajan (L.) Millsp. Photosynthetica 21: 308-313.

32. Lopez FB, Chauhan YS, Johansen C (1997) Effects of timing of drought stress on leaf area development and canopy light interception on short-duration pigeonpea. Journal of Agronomic Crop Science 178: 17.

33. Tayo TO (1982) Growth development and yield of pigeon-pea (Cajanus cajan) cultivar Cita-1 in lowland tropics. 1. Effect of plant population density. Journal of Agricultural Science 98: 65-70. 